\title{
NOTES
}

\section{THE ALASKA RED-TAILED HAWK}

WILLIAM S. CLARK, 2301 South Whitehouse Circle, Harlingen, Texas 78550; raptours@earthlink.net

Grinnell (1909:211) described a new subspecies of the Red-tailed Hawk, Buteo jamaicensis alascensis, as "always blackest dorsally, and decidedly smaller" than a "large series" of Western Red-tailed Hawks, B. j. calurus, at that time the only subspecies of $B$. jamaicensis recognized in western North America. He based his description of this "Alaska Red-tailed Hawk" on four specimens collected in 1907 in southeast Alaska (Figures 1-3), two of which he designated as the type specimens. Grinnell compared the adult type, MVZ $51\left(0^{7}\right)$, with adults of calurus and found it darker dorsally, with a wider dark subterminal tail band, stronger flank barring, and wider black shaft streaks on the belly. The other three specimens comprise a juvenile (MVZ 41), also designated as a type, and both of its parents. The latter (MVZ 42, o; MVZ 43, ơ) are more typical of alascensis in having the breast rufous (Figures 2 and 3). Grinnell wrote that the juvenile type specimen is also darker above and has the dark tail bands wider than those of juvenile calurus; he saw no suggestion of a dark morph in alascensis. So far as known, the range of alascensis comprises the temperate rain forests of southeast Alaska and coastal British Columbia, including the Queen Charlotte Islands (now Haida Gwaii) and western Vancouver Island (see Hellmayr and Conover 1949, Wheeler 2003).

The Western Red-tailed Hawk breeds east of this subspecies' range in British Columbia (Clark and Wheeler 2001), and Harlan's Hawk (B. j. harlani) breeds north of its range, in most of the rest of Alaska, the Yukon, and northwestern British Columbia. Clark and Wheeler (2001) and Liguori and Sullivan (2010) described and depicted the many differences between harlani and the other subspecies of the Red-tailed Hawk.

Field guides to North American birds in general (e.g., Sibley 2000, Dunn and Alderfer 2011) do not describe or depict B. j. alascensis. Clark and Wheeler (2001) and Wheeler (2003) described adult and juvenile plumages of this subspecies in their species accounts, but did not depict them. Other raptor guides (e.g., Wheeler and Clark 2003, Liguori 2005, 2011, Dunne et al. 2012, Crossley et al. 2013) have not described or depicted this subspecies.

I examined 45 specimens of this little-known taxon, including the type specimens, in 10 museums. Gus van Vliet, Chuck Susie, Amy Clark Courtney, and Elleana Elliot sent me more than 20 photos of Red-tailed Hawks taken in southeast Alaska over the last decade. When I replied to van Vliet that they were typical alascensis, he said that he did not know precisely what that was and suggested that I write an article on the field identification of this subspecies so that Red-tailed Hawks in southeast Alaska could be properly evaluated.

Twenty-five of 27 adult alascensis specimens examined, including the adult type (Figures 1-3), have a decided rufous wash on the breast but not much rufous on the belly (Figure 4). In this they differ from the rufous morph of adult calurus, which has a mostly rufous belly (Clark and Wheeler 2001: plate 25, figures 1a and 1f). Interestingly, the adult type specimen lacks this rufous wash (Figure 1). Two of these 27 adult specimens also have some whitish on the breast (perhaps due to interbreeding with harlani). All show much less tawny on the scapulars than does adult calurus (Figures 2-4), most have numerous dark tail bands, and all have a rather wide dark subterminal band (Figure 4) and a rufous breast. Figures 5-7 show adults from southeast Alaska, and Figures 8 and 9 show adults being rehabilitated in (and probably also from) southeast Alaska. 


\section{NOTES}
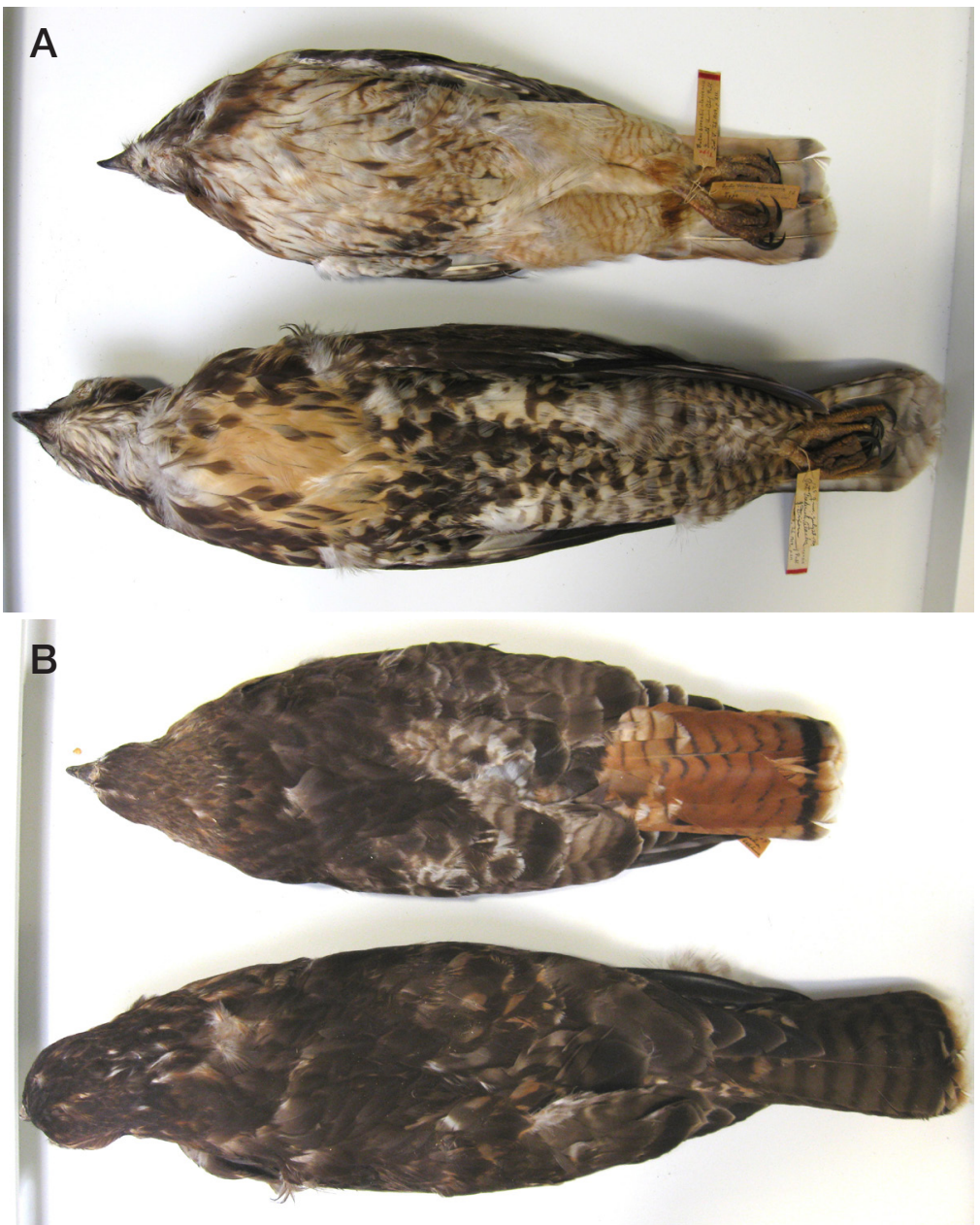

Figure 1. Type specimens of Buteo jamaicensis alascensis. Ventral (A) and dorsal (B) views of MVZ 51, adult o", 10 July 1907, Glacier Bay, coll. Frank Stephens (upper of each pair), and MVZ 41, juvenile o, 28 July 1907, Port Frederick, Chichagof Island, coll. Joseph Dixon (lower of each pair).

Photos by W. S. Clark

Seventeen juvenile specimens differ from the light morph of juvenile calurus by having wider dark tail bands and denser, more blob-like markings on their leg feathers (Figure 10). The upperparts of juvenile alscensis show less whitish mottling, thus appearing darker. Two recently fledged juveniles photographed at Hoonah, Alaska, are very dark, however; the juvenile on the right shows wide dark bands on the upper side of the tail (Figure 11). A juvenile male (USNM 141116) collected in southeast Alaska in summer was beginning its second prebasic molt and shows new rufous breast feathers. 


\section{NOTES}
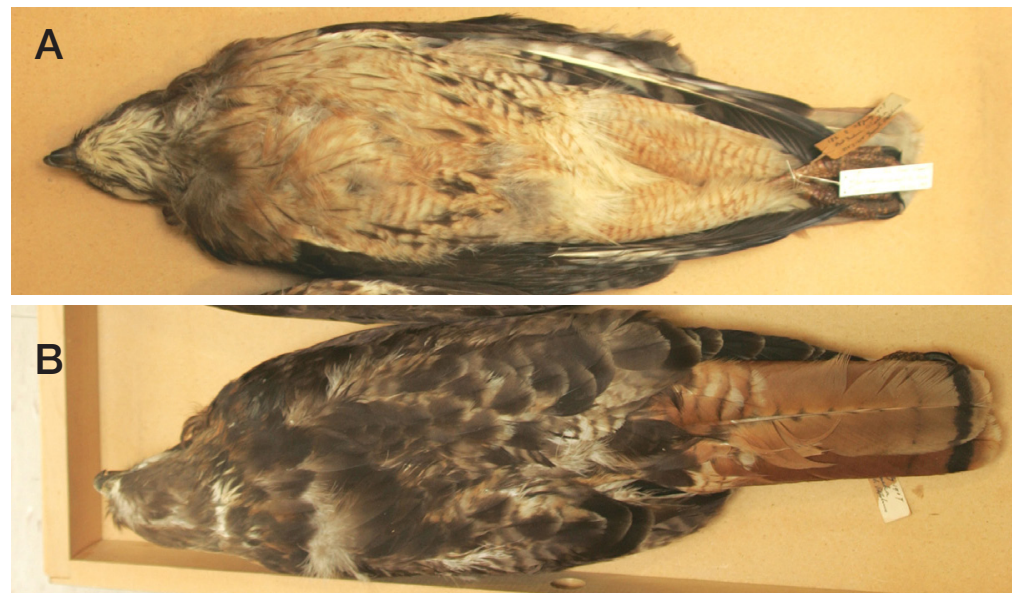

Figure 2. (A) MVZ 43, adult ơ, 28 July 1907, Port Frederick, Chichagof Island, coll. Joseph Dixon; (B) parent of MVZ 41. Note the rufous breast, paler belly, and lack of pale scapulars.

Photos by W. S. Clark

Preston and Beane (2009) reported that adults of B. j. alascensis are much smaller in measurements than those of calurus. In wing chord, eight males of alascensis average $347 \mathrm{~mm}$, whereas 31 males of calurus average $389 \mathrm{~mm}$. Twelve females of alascensis average $361 \mathrm{~mm}$, whereas 36 of calurus average $412 \mathrm{~mm}$. Females of alascensis thus average smaller than males of calurus.

Taverner (1927:18, plate II, bottom bird) illustrated a typical adult alascensis collected on the Queen Charlotte Islands (now Haida Gwaai) during the breeding season.
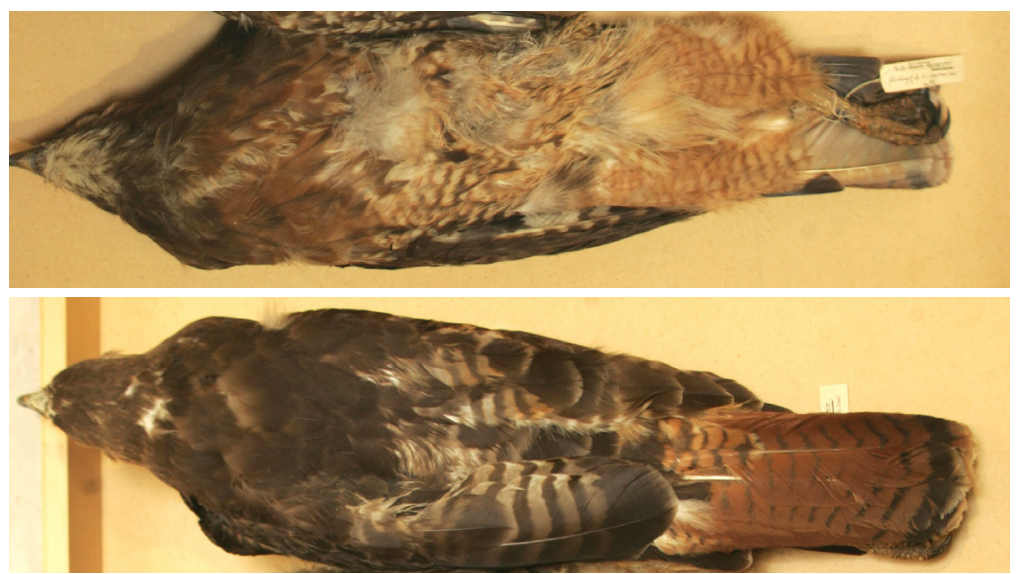

Figure 3. MVZ 42, adult $\uparrow, 28$ July 1907, Port Frederick, Chichagof Island, coll. Joseph Dixon; parent of MVZ 41. Note the rufous breast, paler belly, and lack of pale scapulars. 

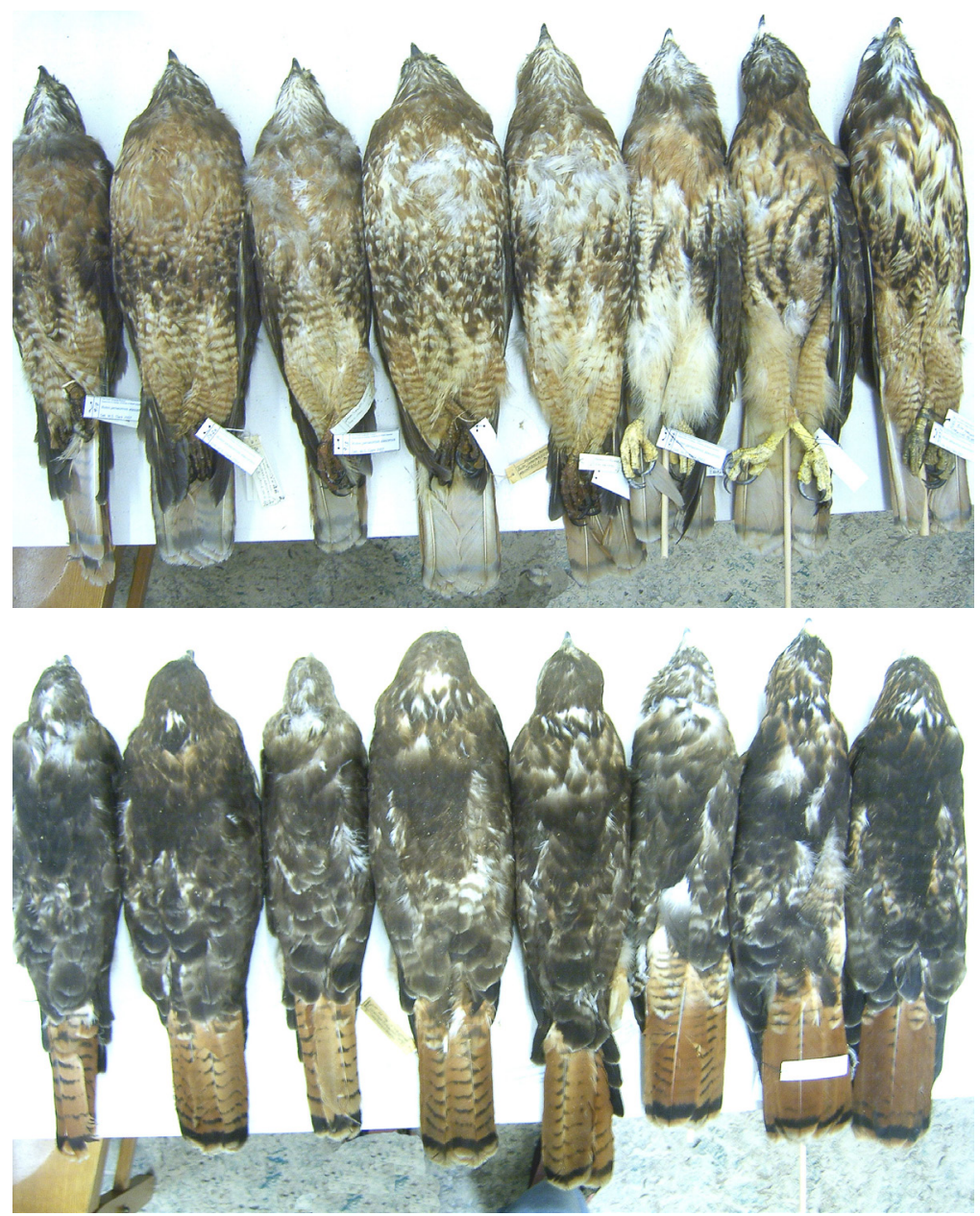

Figure 4. Adults of B. j. alascensis at the Beaty Biodiversity Museum, University of British Columbia, ventral view showing rufous breast and paler belly and dorsal view showing lack of pale markings on scapulars.

Photos by W. S. Clark

It shows the rufous breast and buffy belly of this subspecies. He doubted the validity of this subspecies at that time, however, but later guardedly accepted it on the basis of its smaller size (Taverner 1936).

None of the 45 specimens in 10 museums collected from these areas are of the dark or rufous morph, another difference from the Western Red-tailed. Furthermore, none of the 37 adult and 12 juvenile specimens of dark-morph calurus I examined in 19 museums came from the coastal range of this subspecies.

The status of alascensis as a migrant is not known, although it seems much less 


\section{NOTES}

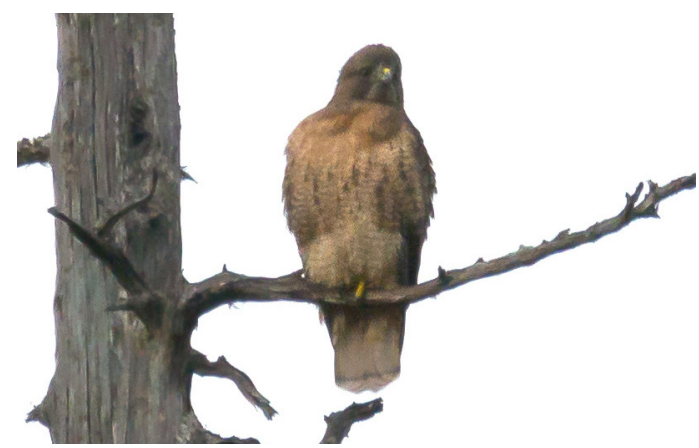

Figure 5. Adult B. j. alascensis, 4 October 2014, near Ketchikan, Revillagigedo Island, Alaska. Note the rufous breast and paler belly.

Photo by Chuck Susie

common north of Juneau in winter than in summer (van Vliet pers. comm.). Heinl and Piston (2009) recorded spring migrants in small numbers near Ketchikan and mentioned only a few winter records. Tobish (2012) reported an extralimital winter record of an adult alascensis on the Kenai Peninsula on 30 December 2011; see photo at N. Am. Birds 66:370, 2012.

The darker coloration of this race conforms with Gloger's Rule (Terres 1980), which states that warm-blooded animals are darker in hot and humid environments and paler in colder and drier ones. The range of $B$. j. alascensis is predominantly the temperate rain forest (Commission for Environmental Cooperation 1997) of southeast Alaska and coastal British Columbia, which extends into western coastal Washington and Oregon, where some nesting birds might also be this subspecies. Red-tailed Hawks of other subspecies breed in more open areas (Preston and Beane 2009). Furthermore, there may be a tendency for raptors breeding in more closed forests to have rufous underparts, as shown by Cooper's Hawk (Accipiter cooperii),

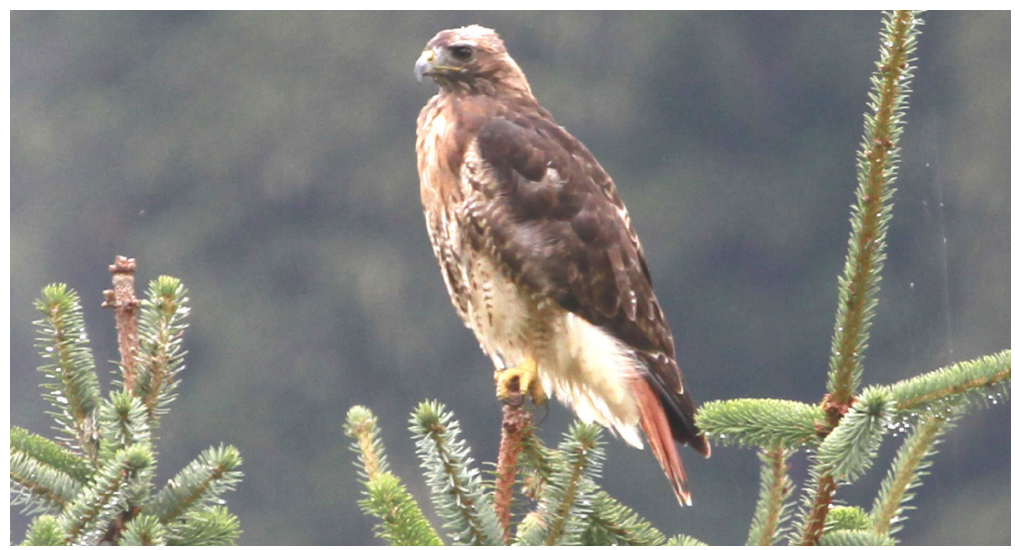

Figure 6. Adult B. j. alascensis, 15 August 2015, near Hyder, Alaska. Note the rufous breast and paler belly.

Photo by Steven C. Heinl 


\section{NOTES}

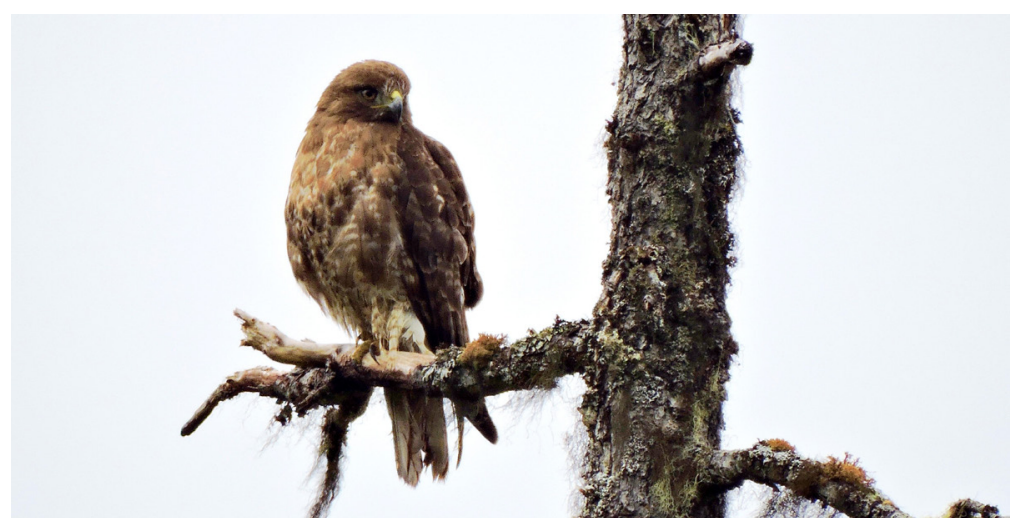

Figure 7. Adult B. j. alascensis, 20 June 2016, Chichagof Island, Alaska. Note the faded rufous breast and paler belly.

Photo by Amy Clark Courtney

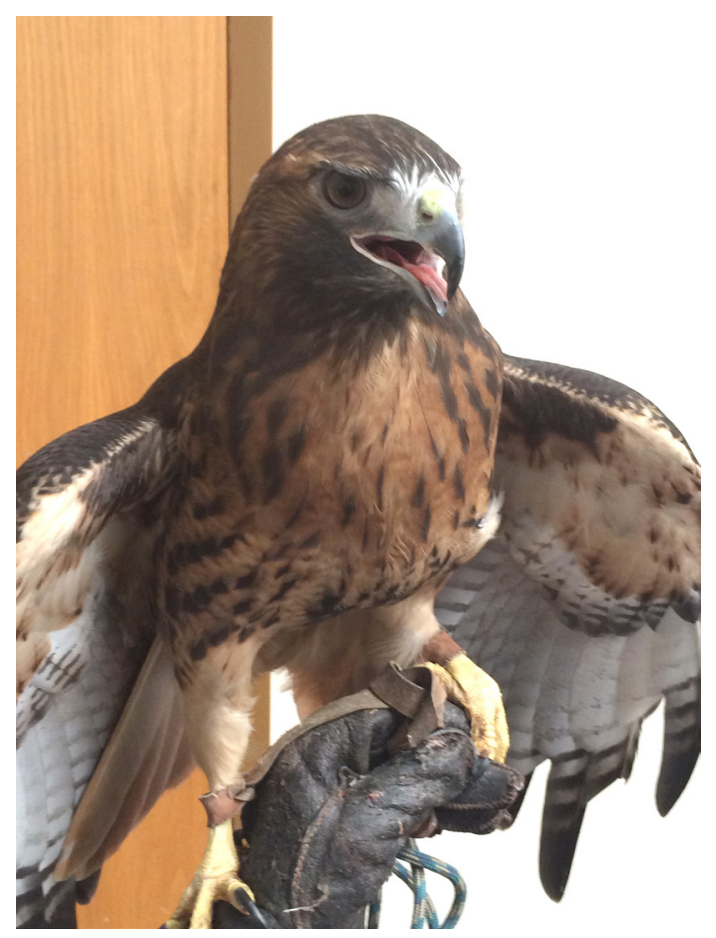

Figure 8. Adult B. j. alascensis, November 2013, in rehabilitation, Juneau, Alaska. Note the rufous breast.

Photo by Gus B. van Vliet 


\section{NOTES}

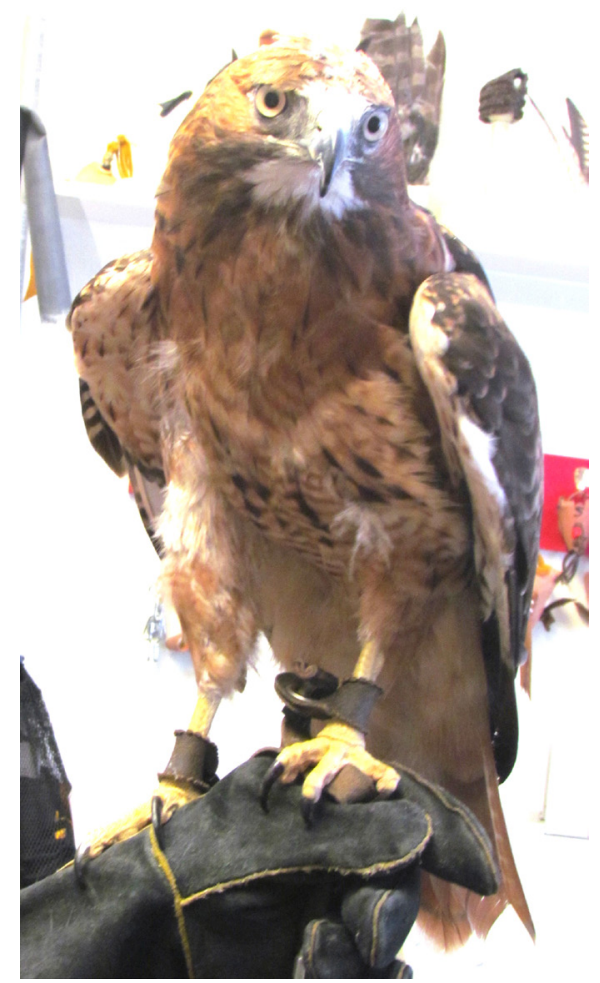

Figure 9. Adult B. j. alascensis, in rehabilitation, Haines, Alaska. Note the rufous breast and paler belly.

Photo by W. S. Clark
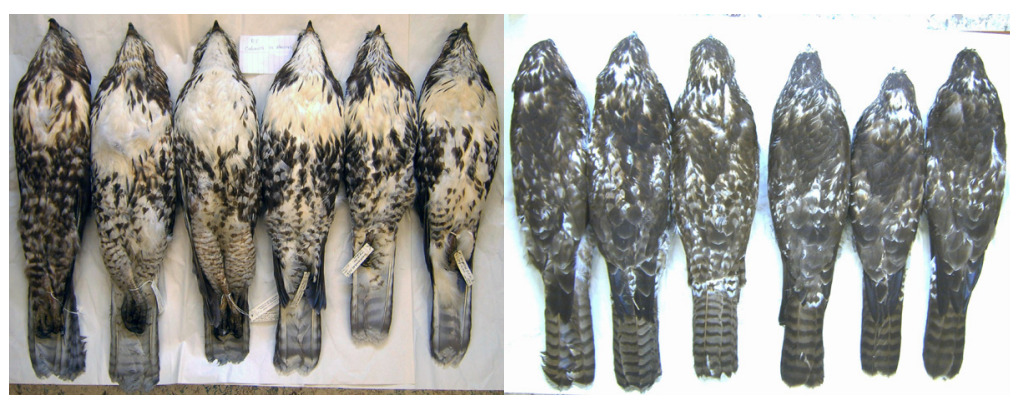

Figure 10. Dorsal and ventral comparison of three juvenile specimens of $B$. j. calurus (left) versus three of juvenile B. j. alascensis (right) at the Beaty Biodiversity Museum, University of British Columbia. Note the wider dark tail bands and blob-like leg markings on the latter. 


\section{NOTES}

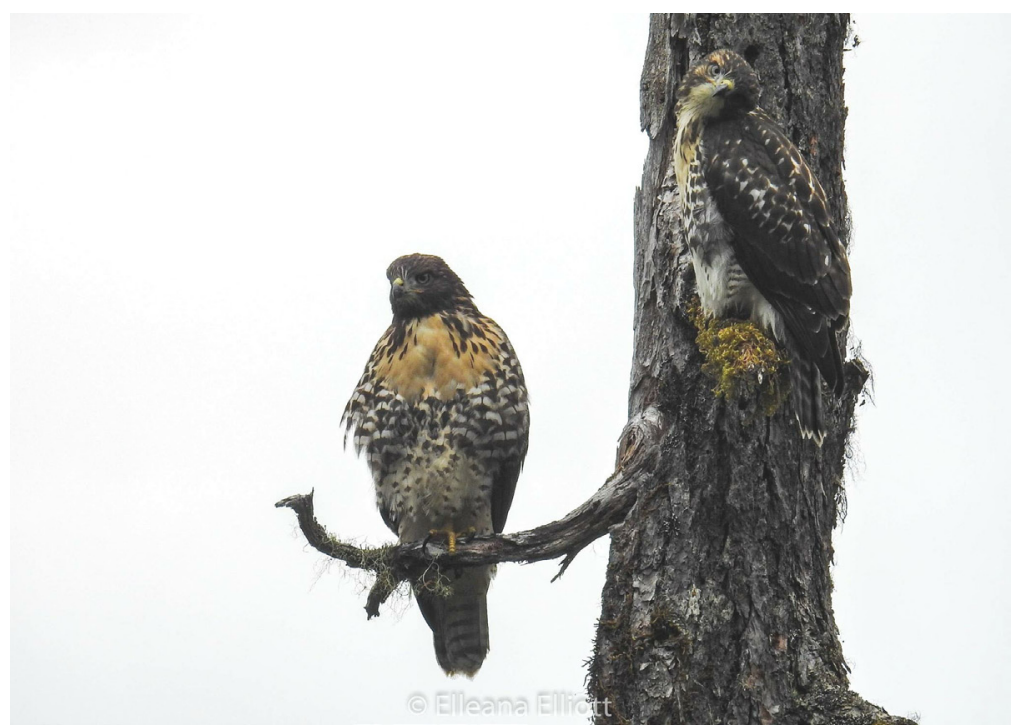

Figure 11. Juveniles of B. j. alascensis, 30 July 2016, Hoonah, Chichagof Island, Alaska. Note the overall dark coloration and wide dark bands on the upper tail of the bird on the right.

Photo by Elleana Elliot

the Sharp-shinned Hawk (A. striatus), and many other forest raptors world-wide, especially accipiters.

I caught and banded an adult Red-tailed Hawk that had some traits of this subspecies, including wing chord $363 \mathrm{~mm}$, near Vancouver, British Columbia, in February 2010 (Figure 12). Note the rufous wash on the breast and the lack of pale markings on the scapulars. Two adults being rehabilitated in southeast Alaska both show a rufous breast (Figures 8-9), but adults in the wild may have the breast faded to rufous-buff or buff. Adults that have rufous areas on the breast have been observed and photographed outside of but near the range of this subspecies, which is to be expected, because of gene flow across subspecies boundaries.

The American Ornithologists' Union's Check-list of North American Birds included B. j. alascensis in its fifth edition (1957), the most recent edition to include subspecies.

Birders and researchers in southeast Alaska should be on the lookout for the Alaska Red-tailed Hawk.

I thank the curators and collection managers of the following museums for permission to examine their valuable bird specimens: American Museum of Natural History, New York City; Beaty Biodiversity Museum, University of British Columbia, Vancouver; Canadian Museum of Nature, Ottawa; Field Museum of Natural History, Chicago; Museum of Vertebrate Zoology (MVZ), University of California, Berkeley; Academy of Natural Sciences of Drexel University (formerly of Philadelphia); Royal Ontario Museum, Toronto; Santa Barbara Natural History Museum, Santa Barbara, California; University of Alaska Museum, Fairbanks; and U.S. National Museum of Natural History (USNM), Smithsonian Institution, Washington, DC. 

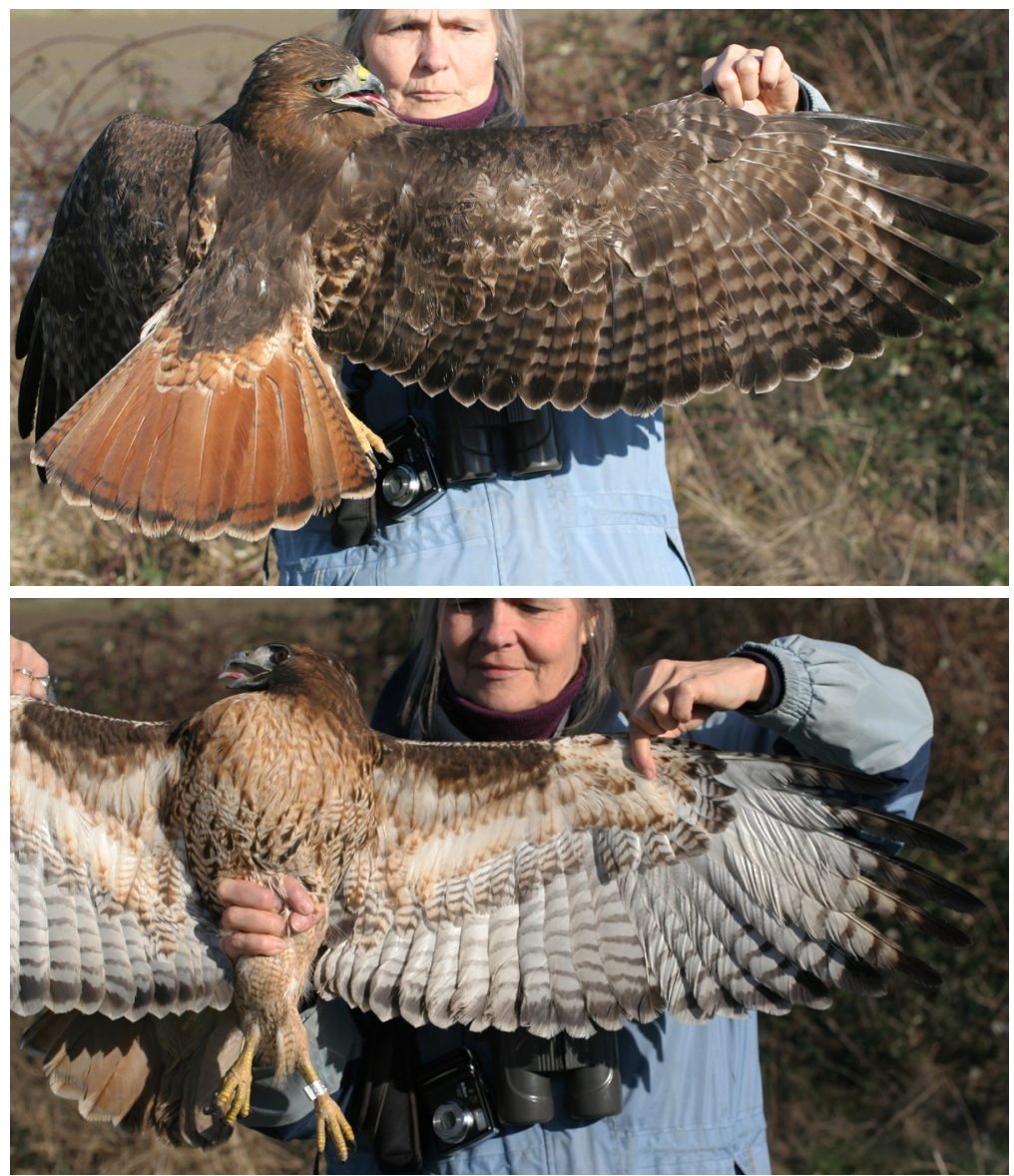

Figure 12. Adult B. j. alascensis, 27 January 2010, Ladner, British Columbia.

Photos by W. S. Clark

Amy Clark Courtney, Elleana Elliot, Chuck Susie, Steven C. Heinl, and Gus B. van Vliet kindly provided photographs for use in this article. Ralph Browning, Dan Gibson, Brian L. Sullivan, Gus B. van Vliet, and Jack J. Withrow provided helpful comments on earlier drafts.

\section{LITERATURE CITED}

American Ornithologists' Union. 1957. Check-list of North American Birds, 5th ed. Am. Ornithol. Union, Baltimore.

Clark, W. S., and Wheeler, B. K. 2001. A Field Guide to Hawks of North America, rev. ed. Houghton Mifflin, Boston.

Commission for Environmental Cooperation. 1997. Ecological regions of North America: Toward a Common Perspective. Comm. for Environ. Coop., Montreal. 


\section{NOTES}

Crossley, R., Liguori, J., and Sullivan, B. L. 2013. The Crossley ID Guide: Raptors. Crossley Books, Cape May, and Princeton Univ. Press, Princeton, NJ.

Dunn, J. L., and Alderfer, J. 2011. Field Guide to the Birds of North America, 6th ed. Natl. Geogr. Soc., Washington, DC.

Dunne, P., Sibley, D., and Sutton, C. 2012. Hawks in Flight, rev. ed. Houghton Mifflin Harcourt, Boston.

Grinnell, J. 1909. Birds and mammals of the 1907 Alexander Expedition to southeastern Alaska. Univ. Calif. Publ. Zool. 5:171-264.

Heinl, S. C., and Piston, A. W. 2009. Birds of the Ketchikan area, southeast Alaska. W. Birds 40:58-144.

Hellmayr, C. E., and Conover, B. 1949. Catalogue of birds of the Americas, part I, no. 4. Zool. Ser. Field Mus. Nat. Hist. 13 (publ. 634).

Liguori, J. 2005. Hawks from Every Angle. Princeton Univ. Press, Princeton, NJ.

Liguori, J. 2011. Hawks at a Distance. Princeton Univ. Press, Princeton, NJ.

Liguori, J., and Sullivan, B. L. 2010. Comparison of Harlan's Hawks with western and eastern Red-tailed Hawks. Birding 42:30-37.

Preston, C. R., and Beane, R. D. 2009. Red-tailed Hawk (Buteo jamaicensis), in The Birds of North America Online (A. Poole, ed.), no. 52. Cornell Lab Ornithol., Ithaca, NY; doi 10.2173/bna52.

Sibley, D. 2000. The Sibley Guide to Birds. Knopf, New York.

Taverner, P. A. 1927. A study of Buteo borealis, the Red-tailed Hawk, and its varieties in Canada. Victoria Mem. Mus. Bull. No. 48 Biol. Series 13:1-25.

Taverner, P. A. 1936. Taxonomic comments on Red-tailed Hawks. Condor 38:66-71; doi $10.2307 / 1363551$.

Terres, J. K. 1980. The Audubon Society Encyclopedia of North American Birds. Knopf, New York.

Tobish, T. 2012. Alaska region (winter 2011-2012). N. Am. Birds 66:329-332.

Wheeler, B. K. 2003. Raptors of Western North America. Princeton Univ. Press, Princeton, NJ.

Wheeler, B. K., and Clark, W. S. 2003. A Photographic Guide to North American Raptors. Princeton Univ. Press, Princeton, NJ.

Accepted 25 October 2017 